\title{
The ultimate strength behaviour of laterised concrete beam
}

\author{
Festus Adeyemi Olutoge ${ }^{1,}$, , Kikelomo Mulikat Adeniran ${ }^{1}$, Oluwatobi Brian Oyegbile ${ }^{2}$ \\ ${ }^{1}$ Department of Civil Engineering, University of Ibadan,Ibadan, Nigeria \\ ${ }^{2}$ Department of Civil Engineering, Federal University Oye-Ekiti,Oye-Ekiti, Nigeria
}

Email address:

fa.olutoge@mail.ui.edu.ng (F. A. Olutoge)

To cite this article:

FestusAdeyemi Olutoge, Kikelomo Mulikat Adeniran, Oluwatobi BrianOyegbile, The Ultimate Strength Behaviour of Laterised Concrete Beam. Science Research,. Vol. 1, No. 3, 2013, pp. 52-58. doi: 10.11648/j.sr.20130103.14

\begin{abstract}
For many years, sand has been predominantly used as fine aggregate in civil engineering construction. More recently, the source of quality sand has been fast diminishing resulting in ever increasing cost of construction. Laterite is now seen as a possible replacement for sand in concrete mix. This paper presents the results of the laboratory tests carried out to investigate the ultimate strength behaviour of laterised concrete. Five classes of specimens incorporating $0,10,20,30$, and $40 \%$ laterite as replacement by weight of sand were prepared. For each specimen class, reinforcement was varied using 2,3 , 4 , and 5 numbers of $10 \mathrm{~mm} \emptyset$ high yield bars as tensile reinforcement- with minimum shear provision, at $300 \mathrm{~mm}$ centers. When subjected to compressive tests using Avery Denison Universal Testing Machine, the compressive strength of normal concrete beam specimens ranges between $17.48 \mathrm{~N} / \mathrm{mm}^{2}$ and $20.39 \mathrm{~N} / \mathrm{mm}^{2}$ while that of laterised concrete ranges between $15.29 \mathrm{~N} / \mathrm{mm}^{2}$ and $35.69 \mathrm{~N} / \mathrm{mm}^{2}$. The analyses showed that laterised concrete beam specimens give satisfactory performance compare to normal concrete beam specimens when the content of laterite in the concrete as partial replacement for sand does not exceed $25 \%$. This result supports the earlier findings that laterised concrete beams can be a satisfactory substitute for normal concrete in building construction.
\end{abstract}

Keywords: Ultimate Strength, Behaviour,Laterised Concrete, Compressive Strength

\section{Introduction}

Laterite soil is used to describe all the reddish residual and non-residual tropically weathered soils, which genetically form a chain of materials ranging from decomposed rock through clays to sesquioxide-rich crusts. This term therefore does not imply any compositional, textural or morphological definition or properties of laterite soils as such; all distinctions useful for engineering purposes are based on the differences in geotechnical characteristics [1]. However, laterised concrete (terracrete) can be defined as concrete in which stable laterite fines replace aggregates of conventional concrete wholly or partially.

The variation in the strength of standard and non-standard concrete specimens under different conditions has been studied extensively [2-5]. Studies into utilisation of laterite as a partial substitute for fine aggregate in concrete production for building purposes has been carried out in an attempts at using locally available materials accumulating on our construction sites as waste products [6]. 'Lanre
Oluwaseyi [7] studied the influence of weather on the performance of laterised concrete.

Ayangade et al. [8] evaluated the effects of different curing methods on the compressive strength of terracrete. Udoeyo et al. [9] investigated the strength performance of laterised concrete (LATCON) when subjected to elevated temperatures of 200,400 and $600^{\circ} \mathrm{C}$. They observed that when subjected to the investigated temperatures, specimens experienced strength losses that increase with temperature. The study further revealed that air-cooled concrete specimens maintained higher residual strength values than water-cooled specimens. Ikponmwosa and Salau [10] conducted an experimental investigation to determine the effect of short randomly oriented and discontinuous steel fibres on the structural behaviour of laterised concrete columns. They observed that there was no appreciable effect of additional steel links on loading when fibres are present in the mix, showing that fibre reinforced laterised concrete short columns may be used without additional steel links in minor structures, as well as low rise buildings, where nominal shear reinforcement is needed. Apeh and Ogunbode 
[11] studied the strength performance of laterised concrete at elevated temperature. The results showed that for the varying percentage replacement of sand with laterite, compressive strength of laterised concrete decreases; and with an increase in temperature, the strength decreases. It was also observed that an air-cooled lateritic concrete specimen has higher residual strength values than watercooled specimens. Udoeyo et al. [12] concluded that the ratio of 28 days compressive strength of non-standard cylinders compared to that of standard $\varnothing 150 \mathrm{~mm} \times 300 \mathrm{~mm}$ cylinders varied from 0.90 to 1.18 , while the split tensile strength varied from 0.46 to 0.91 for the investigated replacement levels of sand by laterite.

\section{Methodology}

\subsection{Materials}

The materials used in this research work include:

- coarse aggregates in form of granite

- fine aggregates in form of sand and laterites

- binder in form of Portland cement

- reinforcement (high yield bars) of size $10 \mathrm{~mm}$

- water for mixing and workability

- planks for shuttering/form works

The properties of Ordinary Portland Cement (OPC) used conform to British standard [13]. In addition, the materials were specified and prepared according to BS 882 [14], BS 5328 [15], and BS 1811 [16].

The classes of test specimens are shown in Table 1.

Table 1.Classes of Test Specimens

\begin{tabular}{cc}
\hline $\begin{array}{c}\text { Specimen } \\
\text { Label }\end{array}$ & $\begin{array}{c}\text { Laterite } \\
\text { Replacement (\%) }\end{array}$ \\
\hline 1 & 0 \\
2 & 10 \\
3 & 20 \\
4 & 30 \\
5 & 40 \\
\hline
\end{tabular}

For each (specimen) class, reinforcement was varied using 2, 3, 4, and 5 (represented by A, B, C, and D respectively) numbers of $10 \mathrm{~mm}$ high yield bars as tensile reinforcement- with minimum shear provision, at $300 \mathrm{~mm}$ centers; as shown in Fig. 1. Hence, there were specimens A1-D1, A2-D2, A3-D3, A4-D4, and A5-D5. 1-5 denoted classes based on \% laterite replacement, while A, B, C, and $\mathrm{D}$ denoted number of reinforcements in beams (i.e. 2, 3, 4, and 5). Class 1 served as a control sample for the study.

The dimension of each beam specimen is $800 \mathrm{~mm} \times 225$ $\mathrm{mm} \times 112.5 \mathrm{~mm}$. Fig. 2 shows the well-fixed wooden formwork.

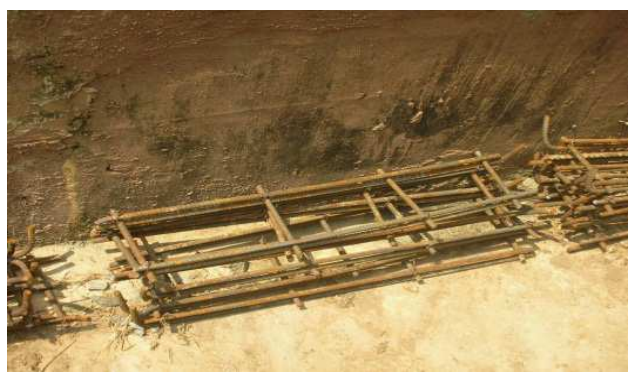

Figure 1. Fixed Reinforcement

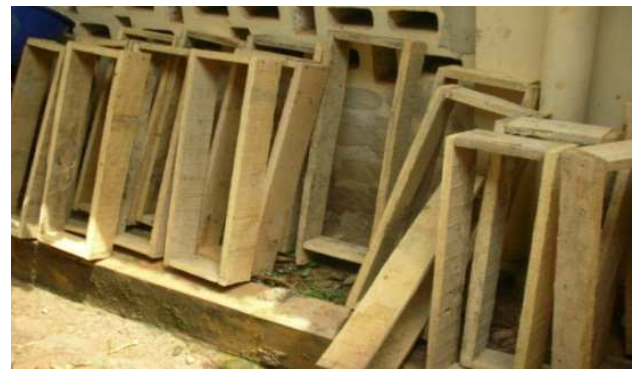

Figure 2. Wooden Formworks

\subsubsection{Batching}

The standard volume of concrete that could be produced from $50 \mathrm{~kg}$ of cement, for a mix ratio of 1:2:4 would be 0.17 $\mathrm{m} 3$. The calculations of the composition for twenty $50 \mathrm{~kg}$ bags of cement are as follows:

The volume of each beam $=0.8 \mathrm{~m} \times 0.225 \mathrm{~m} \times 0.112 \mathrm{~m}$

$$
=0.02025 \mathrm{~m} 3
$$

Hence, the volume of 20 beams $=(20 \times 0.02025) \mathrm{m} 3$

$$
=0.41 \mathrm{~m} 3
$$

The standard quantity of materials that would be required to produce $1 \mathrm{~m} 3$ of concrete, for a mix ratio of $1: 2: 4$ are 238 $\mathrm{kg}$ of cement, $0.33 \mathrm{~m} 3$ of sand and $0.67 \mathrm{~m} 3$ of granite. Material batching for each class of specimens, with corresponding laterite replacements is as follows:

Class 1

$$
\begin{aligned}
& \text { Cement content }=97.58 \mathrm{~kg} / 5 \quad=19.52 \mathrm{~kg} \\
& \text { Sand content }=0.14 \mathrm{~m} 3 / 5 \quad=0.028 \mathrm{~m} 3 \\
& \text { Granite content }=0.28 \mathrm{~m} 3 / 5 \quad=0.056 \mathrm{~m} 3 \\
& \text { Water content }=53.67 / 5 \text { litres }=, 10.74 \text { litres } \\
& \text { Laterite content }=\mathrm{Nil} \\
& \text { Class } 2 \\
& \text { Cement content }=19.52 \mathrm{~kg} \\
& \text { Sand content } \quad=0.028-(10 \% \text { of } 0.028)=0.0252 \mathrm{~m} 3 \\
& \text { Laterite content }=(10 \% \text { of } 0.028)=0.0028 \mathrm{~m} 3 \\
& \text { Granite content }=0.056 \mathrm{~m} 3 \\
& \text { Water content }=10.74 \text { litres } \\
& \text { Class } 3 \\
& \text { Cement content }=19.52 \mathrm{~kg} \\
& \text { Sand content } \quad=0.028-(20 \% \text { of } 0.028)=0.0224 \mathrm{~m} 3 \\
& \text { Laterite content }=(20 \% \text { of } 0.028)=0.0056 \mathrm{~m} 3 \\
& \text { Granite content }=0.056 \mathrm{~m} 3 \\
& \text { Water content }=10.74 \text { litres } \\
& \text { Class } 4 \\
& \text { Cement content }=19.52 \mathrm{~kg} \\
& \text { Sand content } \quad=0.028-(30 \% \text { of } 0.028)=0.0196 \mathrm{~m} 3
\end{aligned}
$$




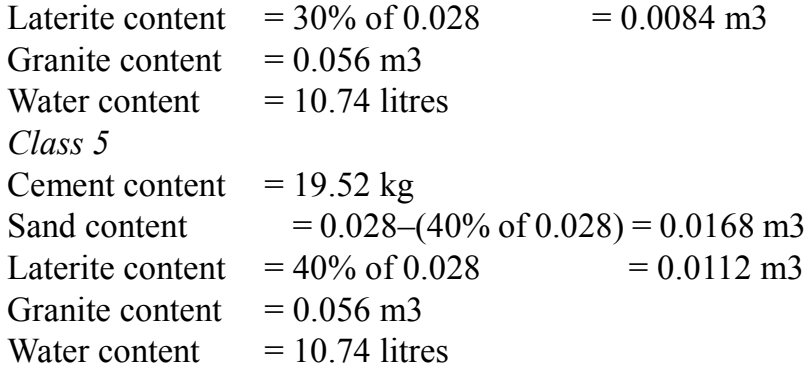

The total quantity of laterite used for the four (4) different replacements $=(10 \%$ of 0.028$)+(20 \%$ of 0.028$)+(30 \%$ of $0.028)+(40 \%$ of 0.028$)$

$$
=((0.1+0.2+0.3+0.4) \times 0.028) \mathrm{m} 3=0.028 \mathrm{~m} 3
$$

Hence, the total required sand content

$$
=(0.14-0.028) \mathrm{m} 3=0.112 \mathrm{~m} 3
$$

The damp sand water content was adjusted accordingly.

Summary of the materials used:

Cement content $=97.58 \mathrm{~kg}$

Sand content $\quad=0.112 \mathrm{~m} 3$

Laterite content $=0.028 \mathrm{~m} 3$

Granite content $=0.28 \mathrm{~m} 3$

Water content $=41.67$ liters

\subsection{Mixing}

The already batched sand and laterite for each class was spread on a clean level hard surface. The correctly measured cement was spread on it and uniformly mixed together. Then, the batchedgranite was spread on top. The accurately quantified clean water was periodically added, according to the water/cement ratio, as the mixing proceeded until a uniform blend was formed.

This procedure was repeated for each of the classes of varying $\%$ of laterite replacement. Hence, there were five different mixes (classes $1-5$ ), with the first mix (i.e. for class 1) as the control mix- it had no laterite replacement.

\subsection{Placing and Compaction}

The moulds were adequately oiled to provide ease of removal of the set concrete without deformation. The fresh concrete mix for each class was fully compacted with tamping rods, to remove trapped air. It was then surfaced-finished. While placing, collision between the concrete and the moulds inner sides were avoided to prevent segregation.

The operations of placing and compacting are basically dependent on each other and therefore, were carried out almost simultaneously. They were carefully done being more important for the purpose of ensuring the requirements of strength, impermeability, and durability of the hardened concrete.

\subsection{Curing}

The cast beams were allowed to set for about 24 hours after casting. Then, they were gently de-moulded i.e. removed from the formworks. A continuous supply of clean water was provided for curing of the beams for 28 days to improve the hydration of the cement paste in the concrete this is necessary for strength development with time.

\subsection{Instrumentation and Test Procedure}

The equipment used for the determination of the ultimate strength of concrete is the Avery Denison Universal Tensile Testing Machine, as shown in Figure 3.

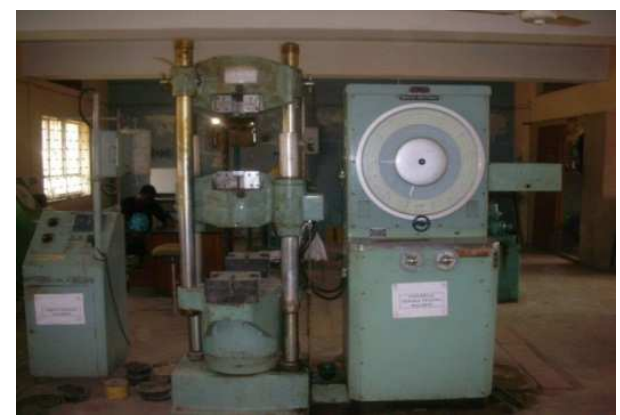

Figure 3. Avery Denison Universal Testing Machine

It is operated based on the principle of hydraulic loading, which induces stress, producing strain effect on the internal structure of concrete. The machine has the load range of $120 \mathrm{kN}$ by $0.2 \mathrm{kN}$ divisions.

At the loading beyond the maximum bearable, failure of the reinforced concrete beams is experienced as the reinforcing bars yield in tension in the bottom and the concrete crushes in compression in the top fibres.

The hardened beam specimens, after 28 days of casting, were removed from the curing basin and allowed to have an adequate surface dryness for some minutes before testing. The test specimens were arranged according to their numbers of reinforcement, i.e. A, B, C, and D, for 2-, 3-, 4-, and 5-bars reinforced beams respectively- with all classes of varying percentage of laterite replacement represented in each collection. Then, collections A1-A5, B1-B5, C1-C5 and D1-D5 were obtained.

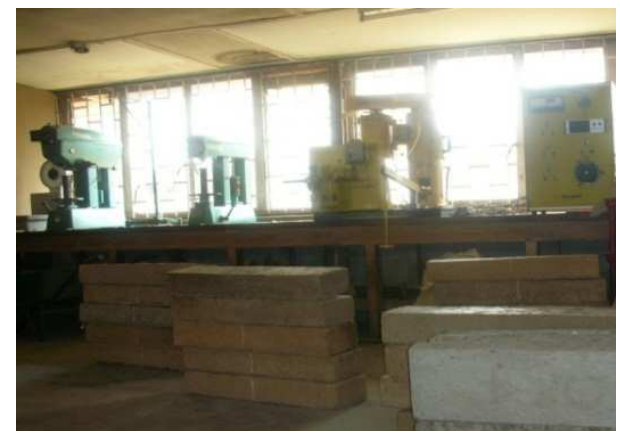

Figure 4. Hardened Beams stacked by numbers of reinforcements

The chosen constant for each collection was the number of reinforcements and the chosen variable was the percentage of laterite replacement, since the effect of the amount of laterite present in a concrete element at its ultimate strength was to be investigated. Their centers were marked with marker to establish their required reference points of application of the point loads. 

5 .

The specimens were subjected to tests as shown in Figure

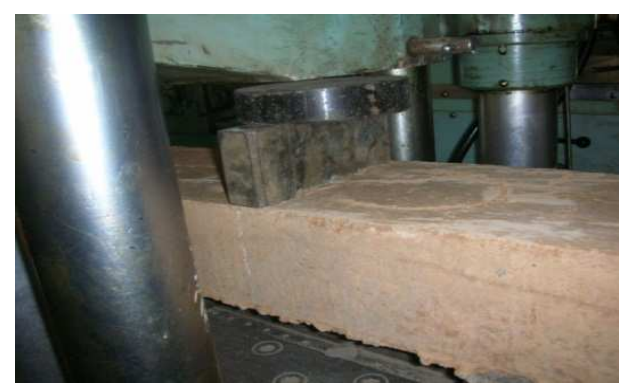

Figure 5. Load Transfer Medium in Place

The first (i.e. initial) crack width in millimeters noticed in each specimen, its corresponding crack load and the various heights at first cracks were appropriately read off and carefully recorded.

At failure load, the final crack width, corresponding crack load and final height at centre mark, for each specimen were taken and recorded. Each of these specimens was then removed from the testing machine and discarded - the discarded beams are shown in Figure 6 and 7; while the calibrating pointers were returned finally to zero reading and the machine switched off.

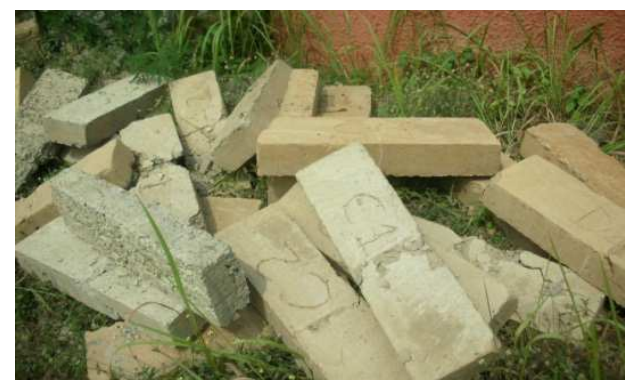

Figure 6. Failed Beam Specimens

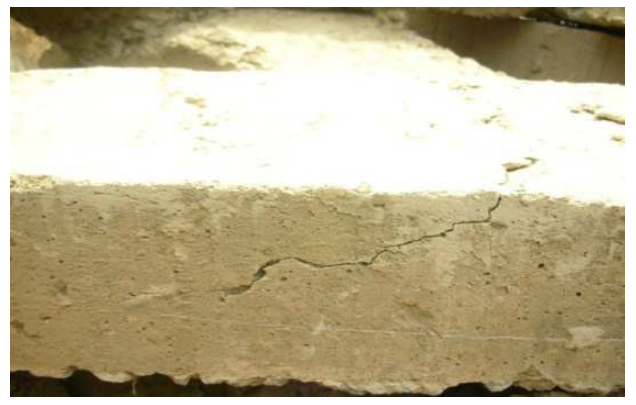

Figure 7. Crack Failure of Beam

\section{Results and Discussion}

\subsection{Beams Behaviour at Initial Crack}

The data from the laboratory test results are analyzed for each class of the specimen of beams, the beams behaviour at initial crack is presented below.

1. Beams of 2-10 mm Reinforcing Bars but Varying \% of Laterite Replacements.
Table 2.Initial Deflection of Beams A1 - A5

\begin{tabular}{cccc}
\hline Beam & Load(kN) & Deflection(mm) & $\begin{array}{c}\text { Crack } \\
\text { Width(mm) }\end{array}$ \\
\hline A1 & 22 & 2 & 1 \\
A2 & 27 & 2 & 1 \\
A3 & 28 & 2 & 1 \\
A4 & 18 & 5 & 1 \\
A5 & 34 & 7 & 1 \\
\hline
\end{tabular}

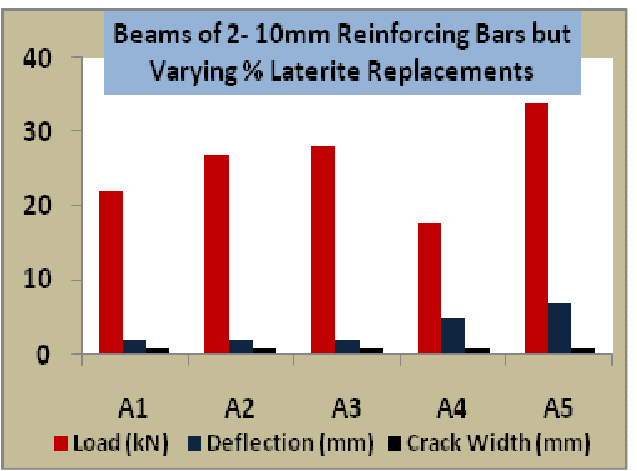

Figure 8. Initial Deflection Chart for Beams A1-A5

2. Beams of 3-10 mm Reinforcing Bars but Varying \% of Laterite Replacements

Table 3.Initial Deflection of Beams B1 - B5

\begin{tabular}{cccc}
\hline Beam & Load(kN) & Deflection(mm) & $\begin{array}{c}\text { Crack } \\
\text { Width(mm) }\end{array}$ \\
\hline B1 & 19 & 2 & 1 \\
B2 & 21 & 3 & 1 \\
B3 & 28 & 2 & 1 \\
B4 & 20 & 2 & 1 \\
B5 & 23 & 3 & 1 \\
\hline
\end{tabular}

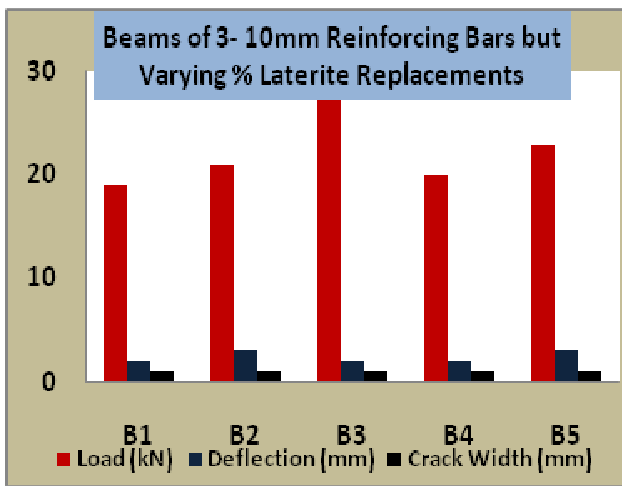

Figure 9. Initial Deflection Chart for Beams B1-B5

3. Beams of 4-10 mm Reinforcing Bars but Varying \% of Laterite Replacements 
Table 4.Initial Deflection of Beams C1 - C5

\begin{tabular}{cccc}
\hline Beam & Load(kN) & Deflection(mm) & $\begin{array}{c}\text { Crack } \\
\text { Width(mm) }\end{array}$ \\
\hline C1 & 24 & 2 & 1 \\
C2 & 34 & 5 & 1 \\
C3 & 28 & 2 & 1 \\
C4 & 26 & 3 & 1 \\
C5 & 28 & 3 & 1 \\
\hline
\end{tabular}

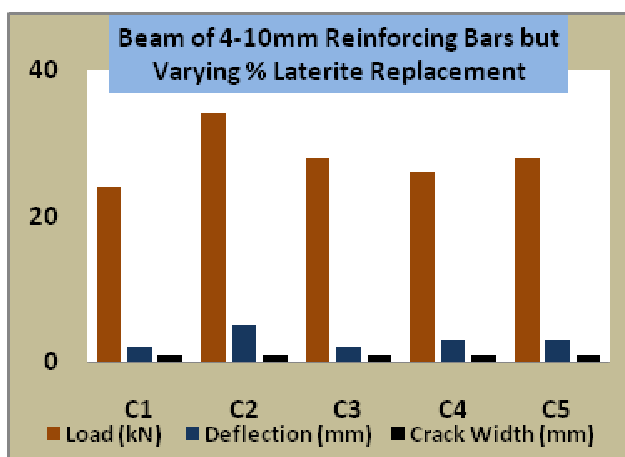

Figure 10. Initial Deflection Chart for Beams C1 - C5

4. Beams of 5-10mm Reinforcing Bars but Varying \% of Laterite Replacements

Table 5.Initial Deflection of Beams D1 - D5

\begin{tabular}{cccc}
\hline Beam & Load(kN) & Deflection(mm) & $\begin{array}{c}\text { Crack } \\
\text { Width(mm) }\end{array}$ \\
\hline D1 & 27 & 3 & 1 \\
D2 & 35 & 2 & 1 \\
D3 & 34 & 3 & 1 \\
D4 & 24 & 2 & 1 \\
D5 & 32 & 3 & 1 \\
\hline
\end{tabular}

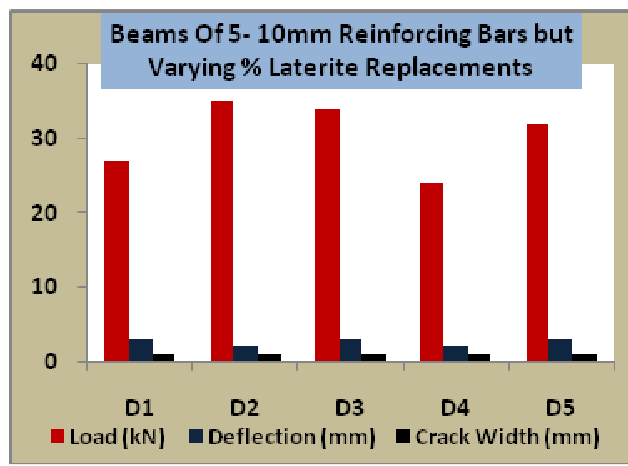

Figure 11. Initial Deflection Chart for Beams D1 - D5

\subsection{Beams Behaviour at Final Crack}

1. Beams of 2-10mm Reinforcing Bars but Varying \% of Laterite Replacements
Table 6. Final Deflection of Beams A1 - A5

\begin{tabular}{cccc}
\hline Beam & Load(kN) & Deflection(mm) & $\begin{array}{c}\text { Crack } \\
\text { Width(mm) }\end{array}$ \\
\hline A1 & 24 & 7 & 2 \\
A2 & 36 & 5 & 2 \\
A3 & 37 & 3 & 2 \\
A4 & 23 & 15 & 3 \\
A5 & 44 & 10 & 3 \\
\hline
\end{tabular}

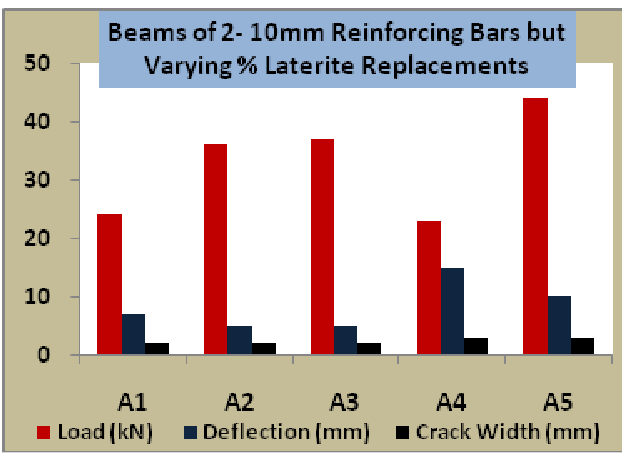

Figure 12. Final Deflection Chart for Beams A1-A5

2. Beams of 3-10mm Reinforcing Bars but Varying \% of Laterite Replacements

Table 7.Final Deflection of Beams B1 - B5

\begin{tabular}{cccc}
\hline Beam & Load(kN) & Deflection(mm) & $\begin{array}{c}\text { Crack } \\
\text { Width(mm) }\end{array}$ \\
\hline B1 & 25 & 10 & 3 \\
B2 & 42 & 5 & 2 \\
B3 & 29 & 6 & 2 \\
B4 & 21 & 3 & 3 \\
B5 & 24 & 7 & 3 \\
\hline
\end{tabular}

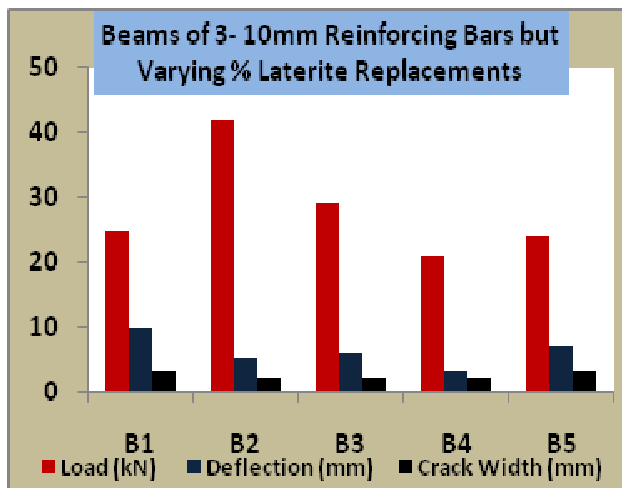

Figure 13. Final Deflection Chart for Beams B1-B5

3. Beams of 4- $10 \mathrm{~mm}$ Reinforcing Bars but Varying \% of Laterite Replacements 
Table 8.Final Deflection of Beams $C 1-C 5$

\begin{tabular}{cccc}
\hline Beam & Load(kN) & Deflection(mm) & $\begin{array}{c}\text { Crack } \\
\text { Width(mm) }\end{array}$ \\
\hline C1 & 27 & 5 & 2 \\
C2 & 49 & 10 & 2 \\
C3 & 42 & 7 & 2 \\
C4 & 31 & 3 & 3 \\
C5 & 38 & 5 & 3 \\
\hline
\end{tabular}

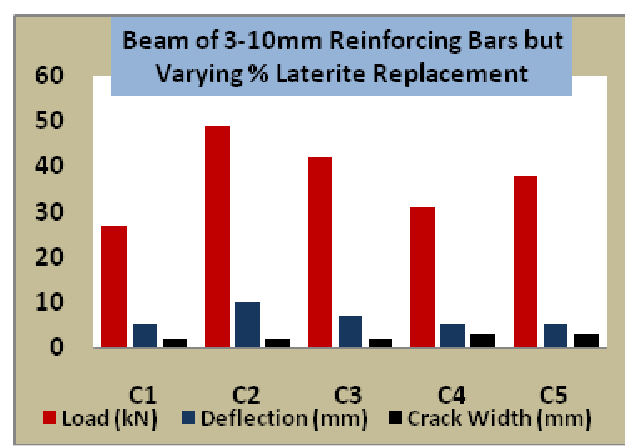

Figure 14. Final Deflection Chart for Beams C1-C5

4. Beams of 5-10mm Reinforcing Bars but Varying \% of Laterite Replacements

Table 9.Final Deflection of Beams D1 - D5

\begin{tabular}{cccc}
\hline Beam & Load(kN) & Deflection(mm) & $\begin{array}{c}\text { Crack } \\
\text { Width(mm) }\end{array}$ \\
\hline D1 & 28 & 7 & 2 \\
D2 & 41 & 5 & 2 \\
D3 & 44 & 6 & 2 \\
D4 & 33 & 6 & 2 \\
D5 & 34 & 5 & 2 \\
\hline
\end{tabular}

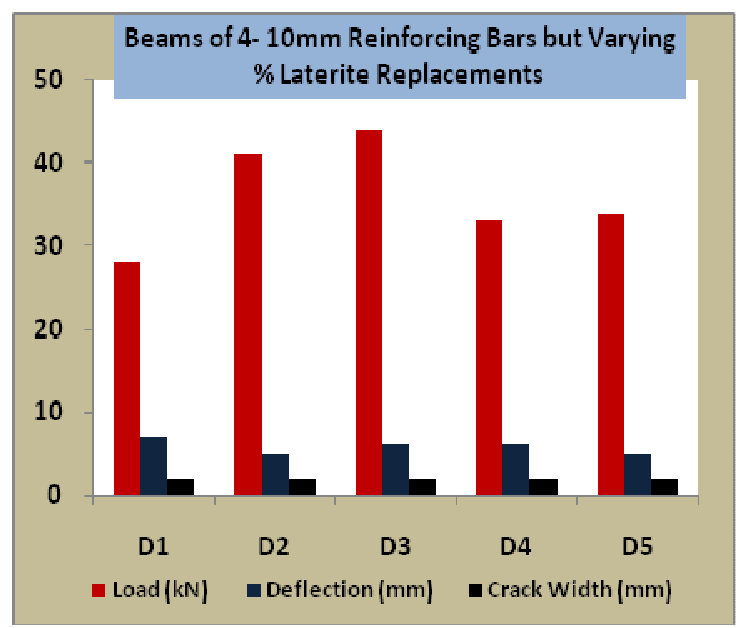

Figure 15. Final Deflection Chart for Beams D1 - D5

\subsection{Compressive Strengths of Laterised Beams of Varying Percentage of Laterite Replacements}

The compressive strengths of the laterised beams of varying percentage of laterite and reinforcement contents are derived from the laboratory data and presented in Table 10 and Figure 16 for classes of tested beams $(A-D)$.

Table 10. Compressive Strengths of All Categories of Number of Reinforcement Content

\begin{tabular}{|c|c|c|c|c|c|c|c|}
\hline & & & & $\%$ of $L$ & ritic $\operatorname{Re}$ & cement & \\
\hline \multirow{5}{*}{ 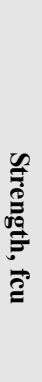 } & \multirow{5}{*}{ 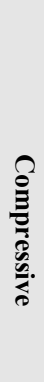 } & & 0 & 10 & 20 & 30 & 40 \\
\hline & & A & 17.480 & 26.220 & 26.949 & 16.752 & 32.047 \\
\hline & & B & 18.209 & 30.590 & 21.122 & 15.295 & 17.480 \\
\hline & & $\mathrm{C}$ & 19.665 & 35.689 & 30.590 & 22.579 & 27.677 \\
\hline & & D & 20.394 & 29.862 & 32.047 & 24.035 & 24.764 \\
\hline
\end{tabular}

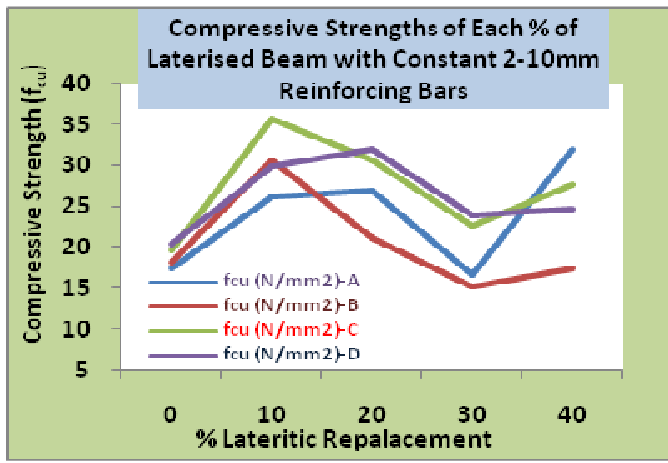

Figure 16. Chart Showing the Compressive Strengths of All Categories of Number of Reinforcement Content

\subsection{Discussion of Results}

The first noticeable crack width in each of the reinforced beam specimens was found to be rounded up to $1 \mathrm{~mm}$, but a crack width of less than $1 \mathrm{~mm}$ is practically possible. The representative maximum crack width was found to be 2 $\mathrm{mm}$.

The measured loadings, at the initial cracks and the final cracks respectively, almost gave an indication that as the number of reinforcement bars increases, the beam's maximum bearable load would increase but for some exceptions - as expected in an ideal situation, for a group of beams of the same make and condition.

The reasonable increase in beam's maximum bearable load as the proportion of laterite in the mix increases also suggested the increasing value effect of laterite on the ultimate strength of the beam specimens of the same reinforcement.

The deflections of the beam as noticed were almost close for the initial cracks but generally not showing an indication of a specific relationship, neither with the 
number of reinforcements nor the percentage laterite replacement. Hence, deflection/load relationship, based on the outcome of the behaviour of the beam specimens could not be suggested.

The compressive strengths relationship of beams with equal number of reinforcing bars but a varying percentage of laterite replacements showed that the compressive strength increased initially between $10 \%$ and $20 \%$ laterite content while there is a decrease in the relationship as the laterite content becomes higher. Similarly, the compressive strengths of the tested beams showed tendency to increase with an increase in the number of reinforcing bars. This suggests that varying the reinforcement bars does improve the strength of laterised concrete.

\section{Conclusion}

The presence of coarse grained good quality-laterite in the making of concrete would not only at least, maintain the ultimate strength of the concrete but could also improve some of its mechanical properties.

Variation in the reinforcement content of laterised beams will have an effect on their performance as it will increase the performance to a threshold value.

Finally, the laterised concrete beam specimens compared well with normal concrete beam specimens at low laterite replacements. For optimum performance of laterised concrete as structural members of a building, the content of laterite replacement in the concrete should not exceed about 25 per cent (one - quarter of sand) in a standard mix.

\section{References}

[1] Gidigasu, M.D., Lateritic Soil Engineering: Pedogenesis and Engineering Principles. Elsevier Scientific Publishing Company, New York. 6p,1976.

[2] Del Viso, J J., Carmona, R. and Ruiz, G.Shape and Size Effects on the Compressive Strength of High Strength Concrete.Cement and Concrete Research.38 (3): 386-395, 2008.

[3] Mansur, M. A. and Islam, M.M. Interpretation of Concrete Strength for Nonstandard Specimens. ASCE J. Mater., 14 (2):
$151-155,2002$.

[4] Yi,S. T., Yang,I.K. and Chol,J.C. Effect of Specimen Sizes, Specimen Shapes, and Placement Directions on the Compressive Strength of Concrete.Nuclear Engineering and Design.236 (2): 115-127, 2006.

[5] Enochsson, O., Lundqvist, J., Täljsten B., Rusinowski, P. and Olofsson, T. CFRP Strengthened Openings in Two-way Concrete Slabs - An Experimental and Numerical Study. Construction and Building Materials. 21(1): 810-826, 2006.

[6] Olawuyi,B. J. and Olusola,K. O.Compressive Strength of Volcanic Ash/Ordinary Portland Laterized Concrete.Civil Engineering Dimension.12(1): 23-28, 2010.

[7] Oluwaseyi, 'Lanre, "The Influence of Weather on the Performance of Laterized Concrete. Journal of Engineering and Applied Sciences. 2(1): 129 - 135, 2007.

[8] Ayangade, J.A., Alake, O., and Wahab, A.B. The Effects of Different Curing Methods on the Compressive Strength of Terracrete. Civil Eng. Dimension. 2(1): 41-45, 2009.

[9] Udoeyo, F. F., Brooks, R., Udo-Inyang, P., and Iwuji, C. Residual Compressive Strength of Laterized Concrete Subjected to Elevated Temperatures. Research Journal of Applied Sciences, Engineering and Technology. 2(3): 262-267, 2010.

[10] Ikponmwosa, E. E. and Salau, M. A. Effect of Short Steel Fibre Reinforcement on Laterized Concrete Columns. J. Sustainable Development. 4(1): 230-239, 2011.

[11] Apeh, J.A. and Ogunbode, E.O. "Strength Performance of Laterized Concrete at Elevated Temperatures," in Proc. 4th WABER Conf., pp289-298. July 24-26 2012, Abuja, Nigeria.

[12] Udoeyo, F.F., Brooks, R., Udo- Inyang, P. and Nsan, R. O., "Early Prediction of Laterized Concrete Strength by Accelerated Testing," IJRRAS, 5(1):10, 2010.

[13] BS12: Specification for Portland Cement, British Standards Institution, London, 1996.

[14] BS 5328: Part 1: Guide to Specifying Concrete, British Standards Institute, London, 1997.

[15] BS 882: Specification for Aggregates from Natural Sources for Concrete, British Standards Institute, London, 1992.

[16] BS1811 - 125: Mixing and Sampling Fresh Concrete in the Laboratory, British Standards Institute, London, 1983. 